\title{
RECENT ROCK ART RESEARCH ON EAST SERAM, MALUKU: A KEY SITE IN THE ROCK ART OF WEST PAPUA AND SOUTH EAST MALUKU
}

\author{
Adhi Agus Oktaviana (D) $1 *$, Peter Van Lape ${ }^{2}$, Marlon NR Ririmasse ${ }^{3}$ \\ ${ }^{1}$ Pusat Penelitian Arkeologi Nasional \\ J1. Raya Condet Pejaten No. 4, Jakarta 12510, Indonesia \\ ${ }^{2}$ University of Washington \\ Seattle, WA 98195-5502, United States \\ ${ }^{3}$ Balai Arkeologi Maluku \\ J1. Namalatu-Latuhalat, Ambon 97118, Indonesia \\ *adhi.agus@kemdikbud.go.id \\ Received: 03/10/2018; revisions: 12/10 - 18/12/2018; accepted: 20/12/2018 \\ Published online: $31 / 12 / 2018$
}

\begin{abstract}
Rock art in Indonesia has been investigated before the 20th century. A number of previous scientific publications noted the existence of rock art sites on Seram Island, Maluku Province, which was on the cliff of Sawai and Tala River. Recent archaeological surveys in the area of East Seram and Seram Laut conducted by a joint Indonesian-American Research Team discovered a new rock art site in the coast of East Seram. The rock art is painted on the cliff wall which is called by the locals as Watu Sika. Rock art on the Watu Sika Site is similar to a number of rock art at other sites in Eastern Indonesia which were mostly painted on karstic cliffs along the coast. This study used verbal and pictorial recording methods using the Dstretch application to clarify images to support identification. This study analyzed a number of figurative and non-figurative patterns of rock art motifs at Watu Sika Site. The results of the identification of a number of rock art motifs on this site show that there are several patterns including figures of human, animal, fish, boats, negative hand stencils, and geometric patterns. This study also discussed an analysis of the social context background of rock art tradition in the surrounding region, particularly at the Banda Sea region. Based on the distribution network of rock art findings in eastern Indonesia, new insights are generated that this interim data analysis show that Watu Sika Site is the key to connecting the distribution path of rock art originating from the western region into two lanes. The first lane to the Northeast, which is the Papua region and South Lane, expanding towards the Islands around the Banda Sea.
\end{abstract}

Keywords: East Seram; Watu Sika site; rock art; Dstretch plugin

\section{INTRODUCTION}

Rock art is part of prehistoric archaeological remains that are very important to reconstruct past life in Indonesian archipelago; its cultural supporters had existed before the Austronesian culture. Hand stencils and animal figure motifs in Leang Timpuseng and a number of other hand stencils in Leang-Leang, Maros, Sulawesi Selatan region, for instance, have inhabited caves for about 13 thousand years between 40,000 and 17,000 years ago. It indicates that long before the Holocene, humans have become creative and imaginative for the fulfillment of their life during the hunting and gathering period (Aubert et al., 2014). Another dating in Indonesian karst region indicates that rock art existed before Austronesian speakers such as in the karst area of Cliff Tutuala which is estimated as old as 30 thousand years (Aubert et al., 2007) and in the Sangkulirang-Mangkalihat karst region, which has a period of around 10,000 years (Plagnes et al., 2003). From the last renewal of rock art dating from Mangkalihat Sangkulirang area, it is known that the dating is contemporaneous to the rock art in Sulawesi, which began about 40,000 years ago (Aubert et al., 2018). Aubert et al. (2018) reveal that there are three phases of dating in the Sangkulirang-Mangkalihat area. Through this dating, it is confirmed that rock art had been started by humans before Austronesian speakers and continued to be developed by supporters of Austronesian culture in eastern Indonesia as some tribes in the Papua coastal areas still create rock art (Arifin, 1997).

In addition to dating progress, technological advances also play a role in rock art recording in 
Indonesia, including the application of 3D laser scanning technology for mapping cave with rock art and also the application of the DStretch plugin in processing photos of rock art objects so they can be displayed more clearly (Oktaviana, 2015). Rock art sites spread from the west to the most eastern region of Indonesia, including cluster sites in Banda Sea area such as in Seram Island, Buru Island, and Kei Islands. Information about rock art in Seram Island was reported more than 70 years ago by Röder in Frobenius expedition on Tala River, West Seram region and around Sawai, in the Northern Coast of Seram (Ririmasse, 2007). The latest archaeological research in the collaboration between Pusat Penelitian Arkeologi Nasional and the University of Washington, United States along with Balai Arkeologi Maluku in 2015 successfully discovered a rock art site that had never been reported before. It is located at the cliff of a small island, Seram Laut, Maluku called as Watu Sika.

The finding of rock art in this area is interesting to be investigated as there are many things to be revealed, such as what motifs are found on the site and unveil its link with other sites in eastern Indonesia. It is because Seram Laut is one of the crossing routes to and from Papua using water transportation since the prehistoric times till the present. The possible similarity of motifs could be a trace of cultural association which might show the human migration path from the Walacea to the Sahul plain. Therefore, the objectives of this study are:

1. Identifying the morphological aspect of rock art in Watu Sika Site, Seram Laut, Maluku.

2. Finding links between Watu Sika site and similar sites in regional rock art geography.

\section{Methods}

This study used a descriptive-qualitative method by processing primary and secondary data sources. Rock art recording on the Cliff was carried out for two days, October 26 and 27 of 2015 by the Research Team. Nikon D7000 DSLR and IFRAO scale were used for pictorial data recording while Leica Disto distance meters was used for measuring the dimension of rock art, and manual meter. Photo taking was performed from the right side of the Cliff and towards the left side of the Cliff. The first photo recording method was photo pane of the image followed by details of the object using a camera with IFRAO scale for two times and without scale two times. The next stage was measuring the length and width of the object, as well as the height of rock art from the terrace surface of the Cliff. Verbal description was performed along with the pictorial recording by describing the types of rock art, drawing techniques, colors, sizes (length and width), height, position, rock art conditions, and rock art orientation (Arifin, 1992; Maynard, 1977; Oktaviana et al., 2016). ImageJ application combined with DStretch plugin were used in data processing in the form of the photograph. DStretch plugin served for clarifying the images or motifs which are generally have faded or covered in moss or overlapped with other motifs (Harman, 2005; Le Quellec, Duquesnoy, \& Defrasne, 2015). After being clarified using the DStretch plugin, rock art motifs were redrawn on CorelDraw application. It aims at making the motives more recognizable.

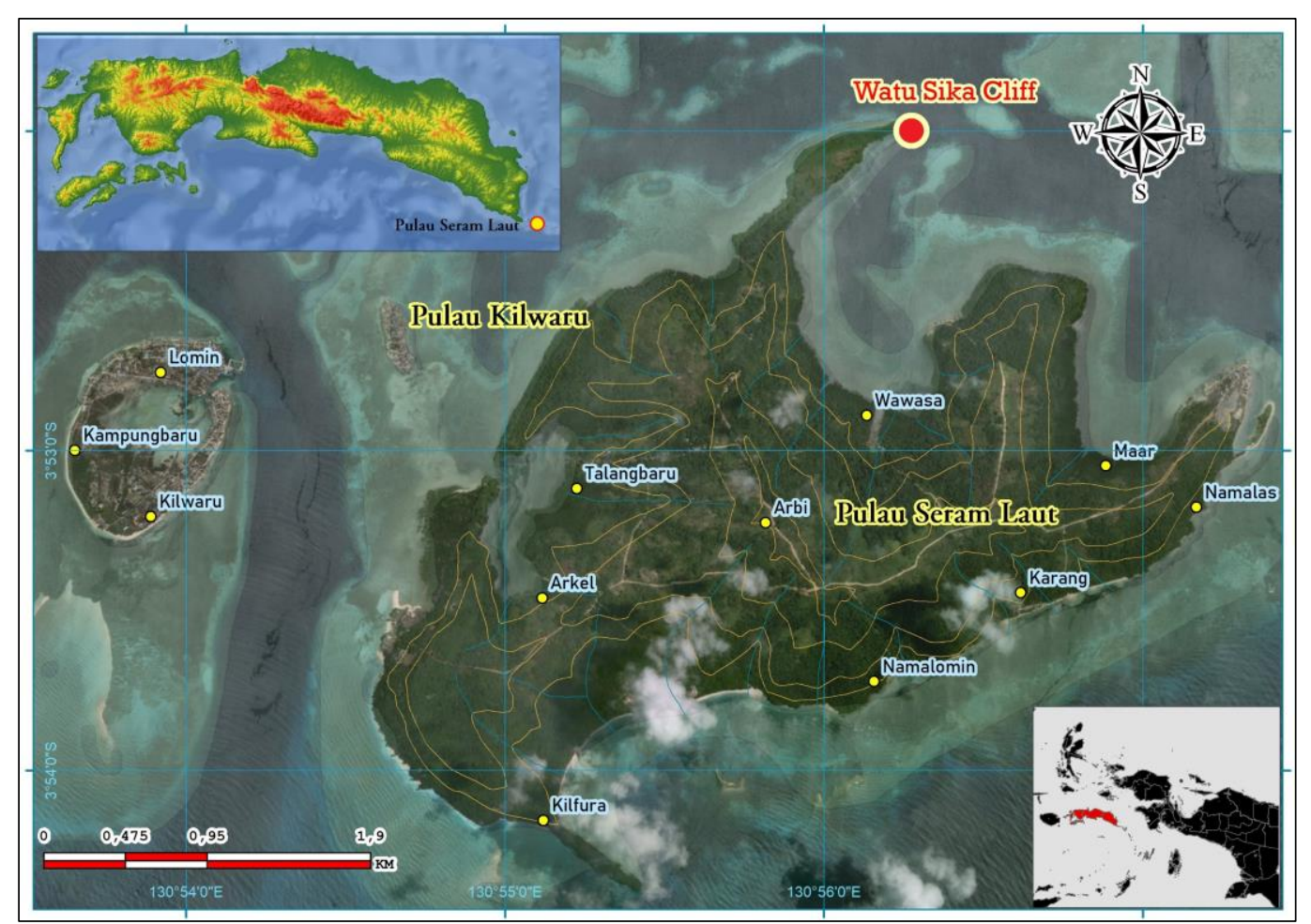

Figure 1. Map location of Watu Sika Site

(Source: Basemap from ESRI World Terrain 2018, edited by Authors) 


\section{RESULT AND DISCUSSION}

\section{Rock Art in the Maluku Islands}

Academic sources about rock art in Maluku was published since approximately a century ago. At that time an Austrian scientist, Röder, published an article entitled Felsiber Auf Seram in Paideuma magazine about rock art in Seram Island (Röder, 1938). In the article, Röder discussed the existence of two rock art sites along the Tala River basin in Western Seram and at Northern Seram Saleman Gulf. These sites were recorded when Röder was taking part in Leo Fronebius Expedition who conducted scientific surveys in Maluku and Papua (Röder, 1959). Archaeological records of rock art in the Maluku Islands then stated by Ballard (1988) who observed the existence of rock art site in Dudumahan, Kei Kecil Island, Kei Islands. Ballard recorded more than 400 rock art motifs which drawn on limestone wall along the Coast of Kei Kecil Island. Ballard estimated that these rock art motifs came from at least more than 2,000 years ago and associated with the mobility of the Austronesian language speakers.

The next record about rock art in Maluku was contributed by Malessy (1999) who recorded the existence of rock art sites in Wamkana, the southern coast of Buru Island. In the Wamkana Site, Malessy discovered human motifs and the geometric motifs in red and black. The existence of rock art sites in Buru Island was identified as a connecting point between rock art sites in Sulawesi and Maluku. Current knowledge of rock art in islands in the southern Maluku was obtained from the results of O'Connor's research (Sue O'Connor et al., 2018) which recorded more than 36 rock art sites at Kisar Island, Maluku Barat Daya district in 2015. A joint research team of Australian National University, Universitas Gadjah Mada, and Balai Arkeologi Maluku recorded hundreds of motifs, some of which were thought to be associated with a cluster of rock arts from sites existing in Timor Island. The identified motifs depicted figures of human, anthropomorphic, dog, fish, boat motifs, and sun motifs.

The latest rock art data in Maluku was contributed by Kealy (Kealy et al., 2018) who recorded the existence of sites with rock art on Wetang Island, Babar Islands. On this small island, Kealy and the team recorded seven rock art sites with human motifs and boat motifs, some of which appeared with wide sails displayed in red. The existence of these sites has formed a large geography rock art sites in the Banda Sea zone and the surrounding region. There have been no studies specifically to observe the chronology of this rock art cluster in a certain way to date. Several attempts were carried out to determine the relative dating by comparing motifs with those in other sites in the area or association with archaeological findings around the sites. Ballard (1988), for instance, tried to connect the chronology of rock art in Kei Islands with a mass migration of Austronesian speakers and estimated that rock art in Kei Islands, was dated from at least 2,000 years ago.

Watu Sika Cliff Site had never been reported in the documentation of rock art in Indonesia. The findings of rock art in the Cliff might be one of the proofs showing the migration path and the distribution of rock art starting from Maluku. From Buru Island, i.e., Waenalut Cave Site and Wamkana at South Buru, to the east, i.e., Papua Barat and to the southeast, which is to Kei Islands, Babar Islands, to Kisar Island, and Tutuala, Timor Leste. Rock art sites in Seram Island has been published so far including Tala River Site and Sawai Site, Maluku Tengah Regency.

\section{Watu Sika Cliff, Seram Laut Island, Eastern Seram, Maluku}

Watu Sika Cliff is located on the north side in the form of the cape in karst cluster Seram Laut Island, Seram Timur Regency, Maluku. Geographically located at the coordinate of $03^{\circ} 51.986^{\prime}$ South Latitude and $130^{\circ} 56.239^{\prime}$ East Longitude with a terrace on the Cliff of 3 to 5 meters above sea level. Along 48 meters of the wall of Watu Sika Cliff, a number of rock art motifs was found. Terrace on Watu Sika Cliff with rock art was generally similar to the one on the seashore of karst region such as in the karst region of Teluk Berau, Kaimana, and South Misool in Papua Barat, as well as in the karst area of Dudumahan on Kei Kecil Island, Kei Islands. Vegetation growing on the surface of the cliff terrace was noni trees and banyan trees, while on the upper surface of the cliff, trees shrubs typical to karst region grew.

The motif displayed was dark red using ochre material (hematite) using brush and spray techniques; the type of painting is in the form of dots, lines, outlines, solids, and negatives. The identified rock art specifically, i.e., human figure, negative hand stencil, boat motif, geometric motif, vertical stripe motif, fish motif, and remnants of unidentified motifs. Many rock arts were faded out; some were covered in moss, insect nests, exposed to water flow, and flaking of the cliff wall. On Watu Sika cliff, the remnants of insect nests were yellowish red, and the natural rocks were red were due to the natural process on the cliff wall which can interfere rock art identification. However, as the materials used for rock art on cliff wall were different, so the rock art motif could be identified, and the remaining of the insect nest and the red color of the rock could be distinguished.

Based on the results of the analysis it is known that there are 66 rock art motifs on this site, consisting of $10.5 \%$ of figurative motifs, $25.7 \%$ of non-figurative motifs, and the total of unidentified motifs were $63.8 \%$ of the remaining motifs. It used spray techniques of 45 
motifs predominantly, brush techniques as many as 20 motifs, and combination of brush and spray technique was 1 motif. The height of the wall panels of rock art from the terrace surface of the cliff up to the ceiling ranged from about 0.7 to 2.5 meters. Rock art panels on the wall of Watu Sika Cliff could be seen by standing on a boat or sitting on a cliff terrace to see the rock art motifs at a close range.

Table 1. List of the number of Rock Art in Watu Sika Cliff

\begin{tabular}{|c|c|c|c|}
\hline Type & $\begin{array}{l}\text { Types of } \\
\text { Rock Art }\end{array}$ & Total & $\begin{array}{l}\text { Percentage } \\
\text { (\%) }\end{array}$ \\
\hline \multirow{4}{*}{$\begin{array}{l}\text { Figurative } \\
7 \text { motifs, } \\
10.5 \%\end{array}$} & $\begin{array}{l}\text { Human } \\
\text { figure }\end{array}$ & 3 & 4.5 \\
\hline & $\begin{array}{l}\text { Animal } \\
\text { figures }\end{array}$ & 1 & 1.5 \\
\hline & Fish Figure & 2 & 3 \\
\hline & Boat motif & 1 & 1.5 \\
\hline \multirow{7}{*}{$\begin{array}{l}\text { Non- } \\
\text { figurative } \\
17 \text { Motifs, } \\
25.7 \%\end{array}$} & Hand stencil & 6 & 9.1 \\
\hline & $\begin{array}{c}\text { Geometric } \\
\text { motifs }\end{array}$ & 4 & 6.1 \\
\hline & Parallel lines & 2 & 3 \\
\hline & Semi-circle & 1 & 1.5 \\
\hline & Curve & 2 & 3 \\
\hline & Crossline & 1 & 1.5 \\
\hline & Other lines & 1 & 1.5 \\
\hline
\end{tabular}

\begin{tabular}{lcc}
\hline $\begin{array}{l}\text { Not } \\
\text { identified }\end{array}$ & 42 & 63.8 \\
\hline Total & 66 & 100 \\
\hline
\end{tabular}

Source: Research Results of 2015

\section{Human Figure}

At least there were three human figure motifs painted on the wall of Watu Sika cliff. Two human figures were illustrated as facing each other on the west side of the cliff using brush techniques on the cliff ceiling at the height of 2.5 meters. The identified human figures on the west side of the cliff included head, hands, and body facing west (see Figure 2, left). Meanwhile, the identified human figures facing east included arm holding a circular object, complete limbs facing east. Other human figures were on the east side of the cliff. The painting technique was a combination of spray and brush techniques at the height of 1.8 meters (see Figure 2, right). On the head of the human figure on the east side of the cliff, there was a decorative pattern like streaks made by pasting two palms and spraying it into a negative semicircle, and then between the fingers, the proportional vertical lines were added and formed semicircle streaks. The head of the human figure was part of the palm of the hand painted using brush technique. For the body, both arms and legs were painted using brush

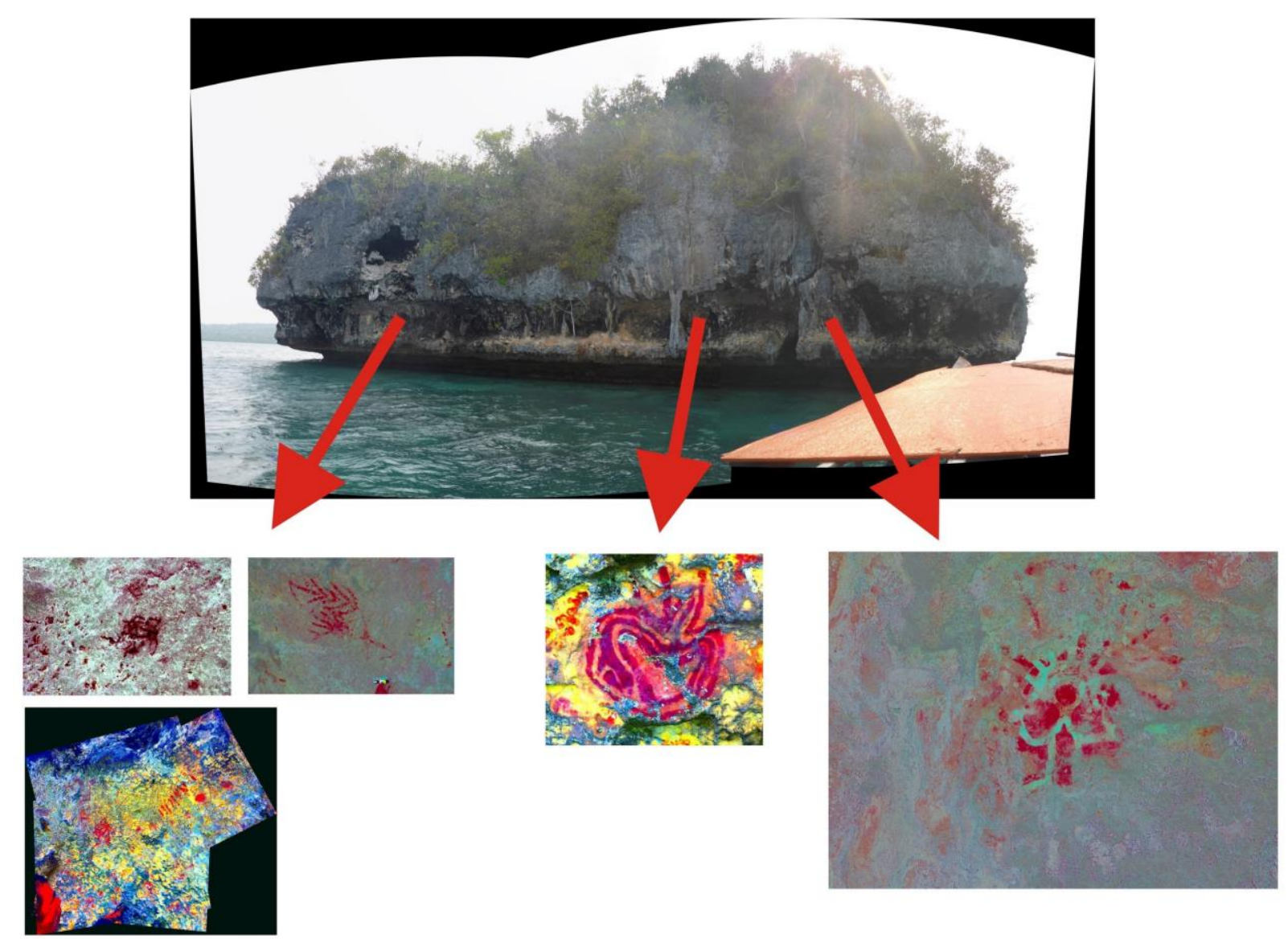

Figure 2. Human figure on Watu Sika Cliff processed with Dstretch plugin (Source: Research Results of 2015) 

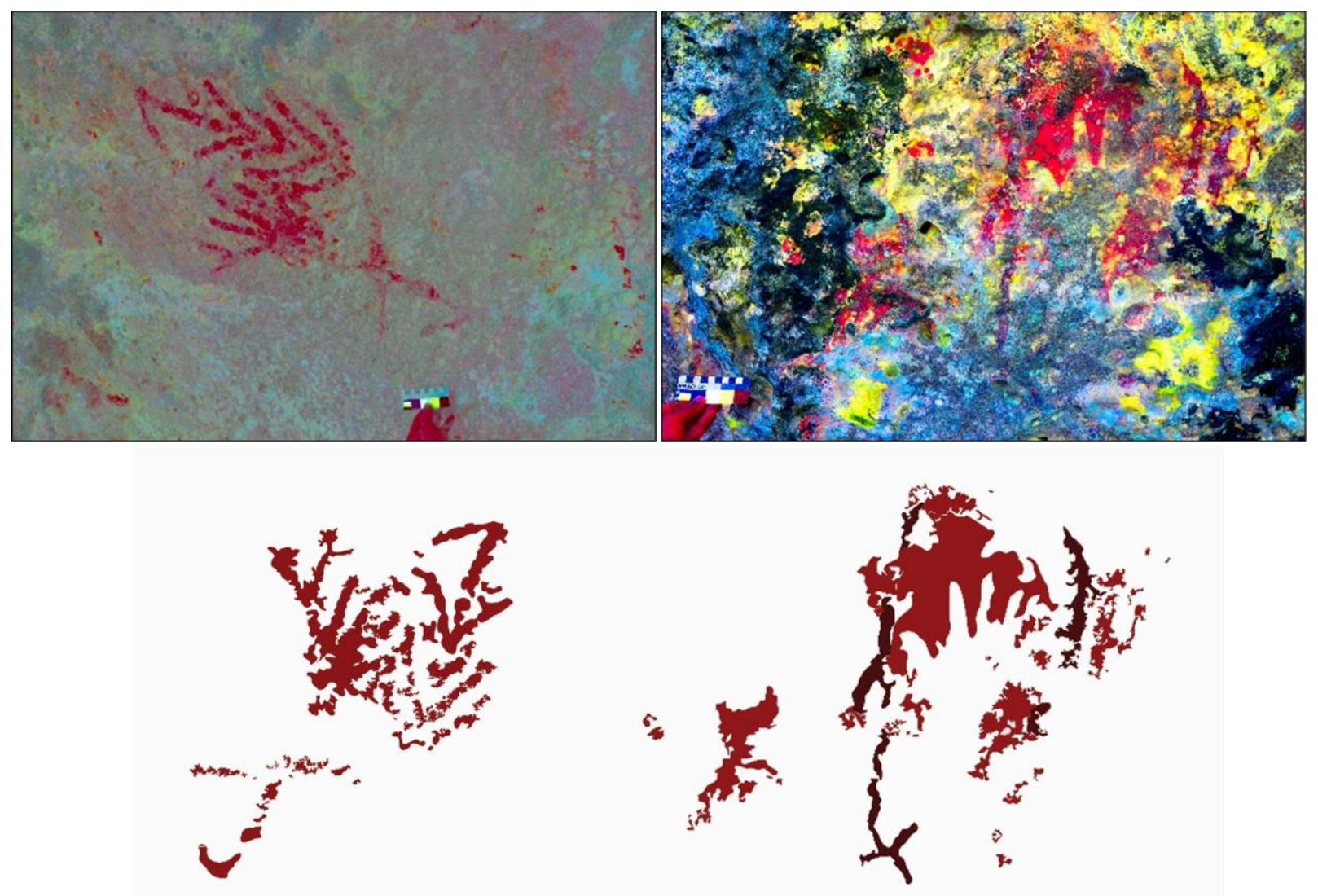

Figure 3. Fish figure (left) and fish figure along with negative hand stencil (right)

(Source: Research Results of 2015)

technique in the form of lines filled with green pigments. The human figures on the south side of the cliff were illustrated resembling a straddling position. In terms of painting techniques, this human figure was unique and indicated that the painter has high creativity in describing human figures. The rock art resembled a human figure made by using red paint from a combination of the two negative hand stencil was not found in other sites in Indonesia and become typical rock art motifs in Seram Laut. The condition of rock arts is generally faded and weathering. For example, the motif of the human figure with an ornament of his head was flaked off on its leg.

\section{Animal and Fish Figures}

Animal motif was recorded only one with an outline shaped brush technique. The motif of the head up to the two legs could be identified. The position of the motif was located at about 2.4 meters above the terrace, the location was on the west side of the cliff, and the condition of the motif covered in moss. Two fish figure motifs were seen on the south side and the west side of the cliff with brush techniques. The first fish figure was painted on the ceiling of the cliff with a height of 2 meters from the terrace surface of the cliff. Based on the fish figures, body and tail were identified with body parts covered with stripes of fishbone (superposition), head with a diagonal position to the right (see Figure 4, left).
The second fish figure was painted upward in dark red, at the height of 1.95 meters from the surface of the cliff terrace. The body part was covered by negative hand stencil, this indicated that the fish figure was painted after the negative hand stencil (see Figure 3, right).

\section{Boat Motif}

The motif assumed to be a boat was found on the wall of Watu Sika cliff in the form of a boat body and a steering wheel on the left in red as pointed to the right, using brush technique. The motif was partially damaged, with possibilities of flaking off and covered by insect nests (see Figure 4). Only red pigment left on the bow of the boat. The rock art motif resembled a boat with one steering wheel. It was also found in the karst area in Muna Island, Sulawesi Tenggara Province, and Tutuala karst region, Timor Leste, in addition to Watu Sika.

\section{Negative Hand Stencil}

On the wall of Watu Sika cliff, 6 motifs with negative hand stencil were found. The hand stencil motifs appeared to be painted using spray technique. One negative hand stencil motif on the west side of the cliff was pointing up at the height of $83 \mathrm{~cm}$ from the surface of the cliff terrace with a middle finger to the palm were identified. While the other five negative hand stencils were on the south of the cliff. Two hand stencil motifs 
were facing up side by side. The right hand up to the wrist motif appeared in superposition coating the fish figure, while it was the only finger identified on the left hand (see Figure 5).

\section{Geometric and Other Non-figurative}

At Watu Sika cliff, it was identified as many as 11 motifs, consisting of 4 geometric motifs, 2 parallel lines motifs, 1 semicircle motif, 2 curved line motifs, 1 cross lines motif, and 1 only line. Geometric motifs generally were markers or symbol of something (see Figure 6).
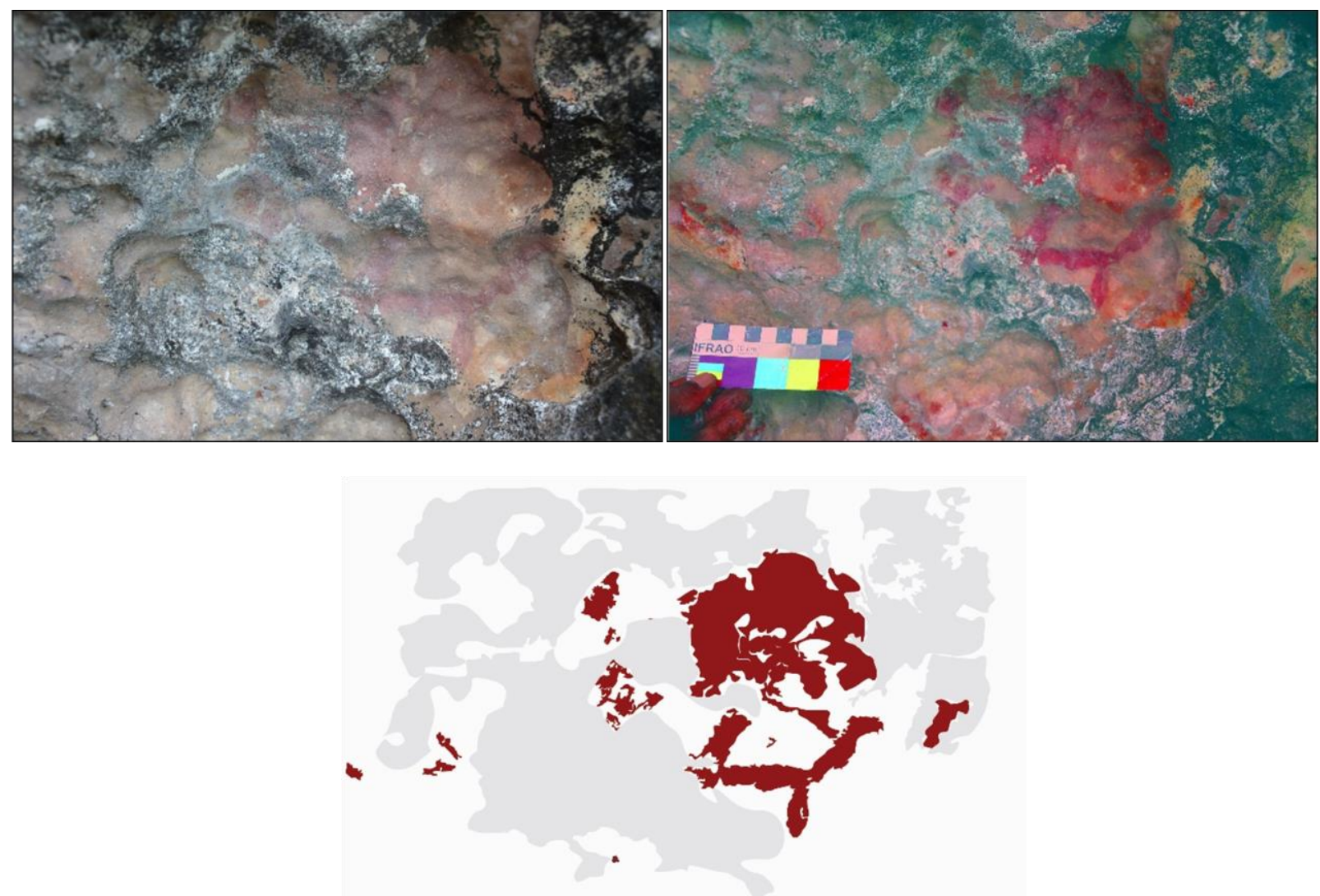

Figure 4. Boat motif

(Source: Research Result of 2015)

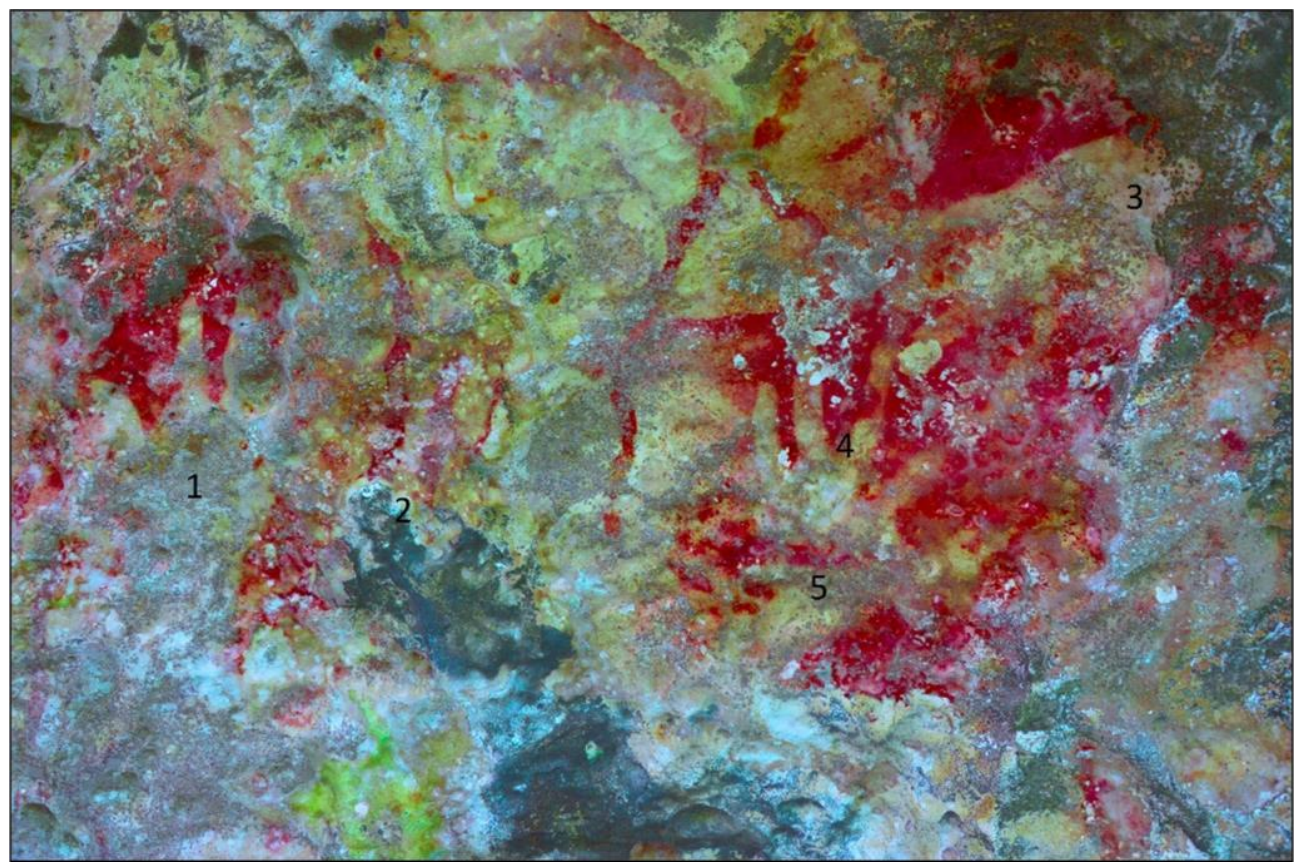

Figure 5. Negative hand stencil (Source: Oktaviana, 2015) 

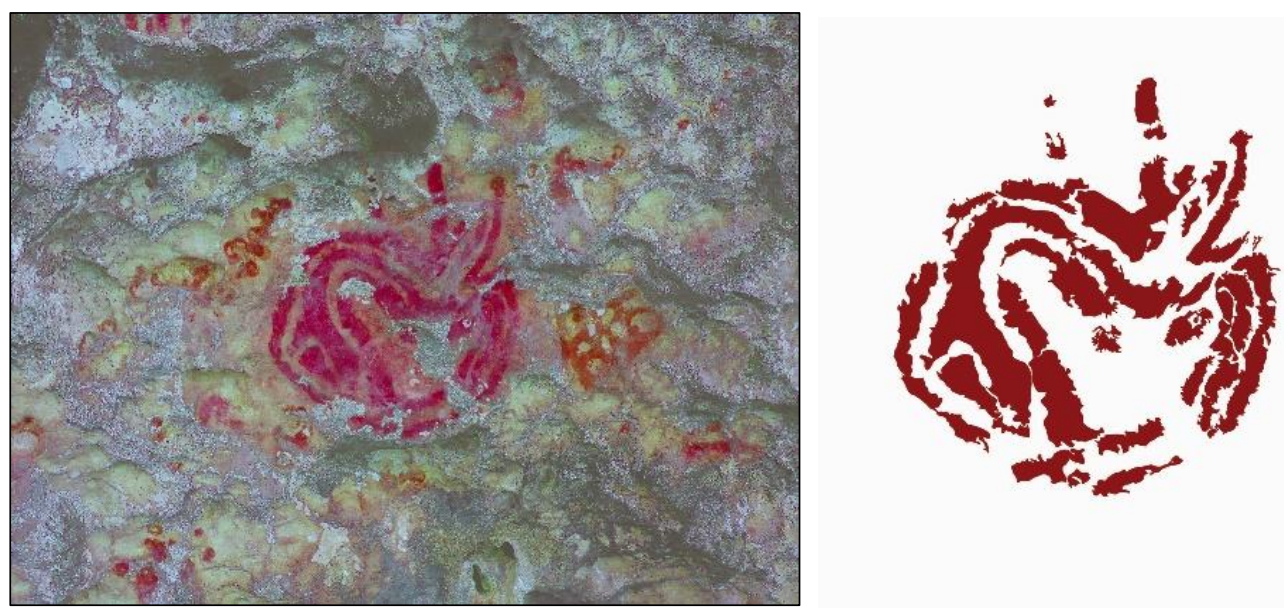

Figure 6. Geometric motif

(Source: Oktaviana, 2015)

\section{Discussion: Rock Art in Maluku as a Past Migration Marker}

While the archaeology of the Banda Sea region is still relatively underdeveloped, this research do have a preliminary understanding of possible migrations and social networks in the area. Underlying these archaeological data is the fact that in the Wallacea region, which has never been connected to continental landmasses, human occupation would have to have been characterized by maritime orientation (e.g., O'Connor, Ono, \& Clarkson, 2011) among archipelago of highly intervisible islands (e.g. Kealy, Shimona, et al., 2018). This would include boat technology and abilities to survive on small islands with relatively low terrestrial productivity by exploitation of marine resources. This maritime orientation suggests that people have always been relatively mobile and therefore connected to a geographically-wide region and likely to have many shared traditions. This presumption of high social connectedness is backed up by the limited archaeological data we have to date. These data come primarily from sourcing or provenience studies on obsidian (Ambrose et al., 2009; C. Reepmeyer, O'Connor, \& Brockwell, 2011; C. Reepmeyer, O'Connor, Maloney, \& Kealy, 2016; Christian Reepmeyer et al., 2011; Spriggs et al., 2011) and earthenware pottery (P. Lape et al., 2018; Peter V. Lape et al., 2017; Peterson, 2015). Linguistic studies also suggest a long period of interaction linking communities in the Banda Sea region (Schapper, 2015). Rock art traditions in the Banda Sea have a presence in the region from the earliest settlement in the Pleistocene (Aubert et al., 2007; O'Connor, Aplin, Pierre, \& Feng, 2010; S. O'Connor \& Oliveira, 2007; Susan O'Connor, 2003).

The existence of rock art in Watu Sika has now provided new information about the distribution of rock art sites in Banda Sea Zone, Maluku Islands. The discovery of this site has integrated the rock art chain into at least two different paths. The first path, the spread of rock art from the west, from Sulawesi Tenggara headed to Southern part of Buru Island (Wamkana), continues to the western of Seram Island (Tala River) headed to the north side of Central Seram (Saleman Gulf) continues to Watu Sika Site. The second path is started from Watu Sika, the distribution path of rock art sites is estimated to continue and link to the Misool Site in Papua, located in the northeastern region of Seram Island or continues to Kei Islands in the south and then spread to Maluku Barat Daya Islands in the south of Banda Sea region like Kisar Island, Babar Island, and Timor Island. Interpretation of this analysis still widely opens considering that there is no study trying to specifically observe the connection and chronology of these rock art sites.

Regarding the aforementioned condition, it is relevant to discuss the existence of Watu Sika Site in relation to a number of other rock art sites around it. The uniqueness of one of the human figure motifs in Watu Sika is the characteristic of this site (see Figure 2, right). Human figures are generally painted using brush technique while parts of the body and head are painted with outlines, solid, or stick figures. At Watu Sika Site, however, human head motif is painted with a combination of spray technique of two hand stencil and brush technique to form a human figure. It indicates that the painter has high creativity by combining two painting techniques of spraying followed by brushing. Regarding the boat motif painted on the wall of this cliff, it suggests that water transportation has been around for a long time in this region. In addition, the transportation between islands by single steer boat indicates that the mileage between islands might be farther than the rowing boat.

For negative hand stencil motif at Watu Sika site, the interesting part is the painting of two hand-stencil facing each other made by spraying techniques was also found in the Sangkulirang Region, Kalimantan Timur; LeangLeang district, Maros; and in Misool Region, Raja Ampat. While for the fish motif, the pattern of the painted motif is similar to the fish motif on rock art in the area of South Misool, Berau Gulf and Maros-Pangkep 
region. This is indicated by the shape of the fish painted outline and generally points upward, either diagonally to the left or right. The similarity of these motifs may be an indication that there are inter-island relations as part of maritime culture recorded on rock art. There is also a superposition in a negative hand stencil and fish figure (see Figure 3, right) interesting to be studied. This painting indicates that the hand stencil motif was painted before figure fish painted on top of it. This might indicate that there is hope in the process of finding fish in the sea. The painter hopes to get large and many fish, or it can also describe gratitude for the fish caught. This interpretation is also used on a number of rock art in the karst area of Maros-Pangkep, Sulawesi Selatan. Painting of animals such as anoa and pigs surrounded by negative hand stencil may have the same meaning in hunting activities (Permana, 2005). Another interesting motif is the geometric pattern resembling the heart shape (see Figure 6). This type of motif is rarely found in rock art in other regions of the archipelago. Circle motifs or parallel lines can be associated with motifs which are described as the 'trans' process of the painter when performing rituals. These motifs are also found in rock art in the Harimau Cave. In addition, they were also found in caves in Sangkulirang-Mangkalihat karst area, Maros-Pangkep karst area, and the karst area in West Papua.

Norman et al. (2017) published the modeling of human migration during prehistory in the Sahul Shelf. The eastern Seram area is one of the important points of human migration towards the Banda Sea in the southern part of the Sahul shelf. This modeling is also supported by Shimona Kealy et al. (2018) who informed that east Seram was the main route for human migration towards Kei Islands and Aru Islands which were part of the Sahul shelf. Boat images are preserved in many of the rock art of the region, as well as in other material cultures such as monumental architecture (Ballard, 1988; Ballard et al., 2004; Peter V. Lape, O'Connor, \& Burningham, 2007; McWilliam, 2007). Although this evidence supports vast interconnectedness, it also suggests that these connections are changed over time, and are structured by geography, ecology and human history of the region (e.g. Ellen, 2003). Rock art analysis can help us further explore how these relationships were structured.

Observation of the possibility of a sample dating using uranium-series on rock art at Watu Sika Cliff was not found. Therefore, putting rock art at Watu Sika Cliff on absolute chronology is impossible. Thus, the prediction of painting time is still limited to relative chronology, which is by matching only motifs similarities painted in rock art on the adjacent territory. To date, the absolute dating of rock art in eastern Indonesia is still unknown. Furthermore, it is interesting to observe the possibility of identifying cultural support groups that are linked to the chronology of the age of rock art sites in the region. Although it is still early, denoting an association of this site in relation to past human migration in the Maluku Islands is possible. During this time, knowledge of massive migrations in the prehistoric era in the scope of Southeast Asia and Australia is generally attached to two major migration processes. The first is the migration of modern human from Mainland Asia (Sunda Shelf) to Great Land of Australia for colonization of Sahul Shelf in the Pleistocene age. Second, the migration process of Austronesian language speakers which lasted from 3,500 to 1,200 years ago.

\section{Conclusion}

Rock art findings on Watu Sika Cliff, Seram Laut provide current data information on the distribution of rock art sites in the Banda Sea. Moreover, these findings also become a reinforcing evidence of prehistoric human migration path from Wallacea towards the Sahul Shelf. Preservation and conservation of rock art figures at Watu Sika Cliff are required since the conditions of the number of rock art motifs are estimated to be degraded due to flaking. Furthermore, analysis of the pigments and absolute dating is required to determine the chronology of this Cliffs either they are Pleistocene age or Austronesia speakers remains.

\section{ACKNOWLEDGEMENT}

We would like to express our gratitude to all members of the Research Team involved in collecting the data in the eastern Seram Island region in 2015. We would also thank all parties involved in contributing the information, data, and thoughts during the preparation of this publication, as well as to all members of the Editorial Board and two Anonymous Reviewers in Kapata Arkeologi who assisted us maintaining the quality of this scientific publication until it can be published. We hope that this scientific publication may give a real impact on the advancement of science. 


\section{REFERENCES}

Ambrose, W., Allen, C., O'Connor, S., Spriggs, M., Oliveira, N. V., \& Reepmeyer, C. (2009). Possible obsidian sources for artifacts from Timor: narrowing the options using chemical data. Journal of Archaeological Science, 36(3), 607-615.

Arifin, K. (1992). Laporan Penelitian Lukisan Batu Karang di Indonesia: Suatu Evaluasi Hasil Penelitian. Depok: Departemen Pendidikan dan Kebudayaan, Lembaga Penelitian Universitas Indonesia.

Arifin, K. (1997). Penelitian Rock Art di Indonesia: dari deskripsi hingga pencarian makna. In Seminar Hasil Penelitian Bidang Sosial Budaya. Depok: Pusat Penelitian Masyarakat dan Kebudayaan, LP-UI.

Aubert, M., Brumm, A., Ramli, M., Sutikna, T., Saptomo, E. W., Hakim, B., ... Dosseto, A. (2014). Pleistocene Cave Art from Sulawesi, Indonesia. Nature, 514(7521), 223.

Aubert, M., O'Connor, S., McCulloch, M., Mortimer, G., Watchman, A., \& Richer-LaFleche, M. (2007). Uraniumseries dating rock art in East Timor. Journal of Archaeological Science, 34(6), 991-996.

Aubert, M., Setiawan, P., Oktaviana, A. A., Brumm, A., Sulistyarto, P. H., Saptomo, E. W., ... \& Zhao, J. X. (2018). Palaeolithic cave art in Borneo. Nature, 564(7735), 254-257.

Ballard, C. (1988). Dudumahan: a rock art site on Kai Kecil, SE Moluccas. Bulletin of the Indo-Pacific Prehistory Association, 8, 139-161.

Ballard, C., Bradley, R., Myhre, L. N., \& Wilson, M. (2004). The ship as symbol in the prehistory of Scandinavia and Southeast Asia. World Archaeology, 35(3), 385-403.

Ellen, R. F. (2003). On the edge of the Banda zone: Past and present in the social organization of a Moluccan trading network. University of Hawaii Press.

Harman, J. (2005). Using decorrelation stretch to enhance rock art images. In American Rock Art Research Association Annual Meeting. sn.

Kealy, S., Louys, J., \& O'Connor, S. (2018). Least-cost pathway models indicate northern human dispersal from Sunda to Sahul. Journal of Human Evolution, 125, 59-70.

Kealy, S., Wattimena, L., \& O'Connor, S. (2018). A Geological and Spatial Approach to Prehistoric Archaeological Surveys on Small Islands: Case Studies from Maluku Barat Daya, Indonesia. Kapata Arkeologi, 14(1), 1-14.

Lape, P. V., Aziz, F. A., Ekowati, D., Huff, J., Handoko, W., Huwae, A., \& Zenobi, L. (2017). Reframing the Island Southeast Asian Neolithic: Local vs regional adaptations. In B. Prasetyo, T. S. Nastiti, \& T. Simanjuntak (Eds.), Austronesian Diaspora: A New Perspective (pp. 65-76). Yogyakarta: Gadjah Mada University Press.

Lape, P. V., O'Connor, S., \& Burningham, N. (2007). Rock Art: A Potential Source of Information about Past Maritime Technology in the South-East Asia-Pacific Region. International Journal of Nautical Archaeology, 36(2), 238-253.

Lape, P. V, Peterson, E., Tanudirjo, D., Shiung, C. C., Lee, G. A., Field, J., \& Coster, A. (2018). New data from an open Neolithic site in eastern Indonesia. Asian Perspectives, 57(2), 222-243.

Le Quellec, J. L., Duquesnoy, F., \& Defrasne, C. (2015). Digital image enhancement with DStretch ${ }^{\circledR}$ is complexity always necessary for efficiency?. Digital Applications in Archaeology and Cultural Heritage, 2(23), 55-67.

Malessy, E. (1999). Laporan Penelitian Arkeologi Prasejarah di Buru Selatan, Kecamatan Buru, Propinsi Maluku. Ambon: Balai Arkeologi Ambon.

Maynard, L. (1977). Classification and Terminology in
Australian Rock Art. In P. J. Ucko (Ed.), Form in Indigenous Art Schematisation in the Art of Aboriginal Australia and Prehistoric Europe (pp. 387-403). Canberra: Australian Institute of Aboriginal Studies.

McWilliam, A. (2007). Austronesians in linguistic disguise: Fataluku cultural fusion in East Timor. Journal of Southeast Asian Studies, 38(2), 355-375.

Norman, K., Inglis, J., Clarkson, C., Faith, J. T., Shulmeister, J., \& Harris, D. (2018). An early colonisation pathway into northwest Australia 70-60,000 years ago. Quaternary Science Reviews, 180, 229-239.

O'Connor, S. (2003). Nine New Painted Rock Art Sites from East Timor in the Context of the Western Pacific Region. Asian Perspectives, 42, 97-128.

O'Connor, S., Aplin, K., St Pierre, E., \& Feng, Y. X. (2010). Faces of the ancestors revealed: discovery and dating of a Pleistocene-age petroglyph in Lene Hara Cave, East Timor. Antiquity, 84(325), 649-665.

O'Connor, S., Mahirta, Tanudirjo, D., Ririmasse, M., Husni, M., Kealy, S., ... Alifah. (2018). Ideology, Ritual Performance and Its Manifestations in the Rock Art of Timor-Leste and Kisar Island, Island Southeast Asia. Cambridge Archaeological Journal, 28(2), 225-241.

O'Connor, S., \& Oliveira, N. V. (2007). Inter- and Intraregional Variation in the Austronesian Painting Tradition: A View from East Timor. Asian Perspectives, 389-403.

O’Connor, S., Ono, R., \& Clarkson, C. (2011). Pelagic Fishing at 42,000 Years Before the Present and the Maritime Skills of Modern Humans. Science, 334(6059), 1117 1121.

Oktaviana, A. A. (2015). Pengaplikasian DStretch Pada Perekaman Gambar Cadas di Indonesia. In Diskusi Ilmiah Arkeologi. Jakarta: Ikatan Ahli Arkeologi Indonesia.

Oktaviana, A. A., David, B., Sue, O., Budianto, H., Suryatman, Wibowo, ... Fahri. (2016). Hand Stencils With And Without Narrowed Fingers at Two New Rock Art Sites in Sulawesi, Indonesia. Rock Art Reseach, 33(1), 32-48.

Permana, R. C. E. (2005). Bentuk Gambar Telapak Tangan Pada Gua-Gua Prasejarah di Kabupaten Pangkajene Kepulauan, Sulawesi Selatan. Wacana, 7(2), 161-174.

Peterson, E. J. (2015). Insularity and Adaptation: Investigating the Role of Exchange and Inter-island Interaction in the Banda Islands, Indonesia. Doctoral dissertation, University of Washington.

Plagnes, V., Causse, C., Fontugne, M., Valladas, H., Chazine, J. M., \& Fage, L. H. (2003). Cross dating (Th/U-14 C) of calcite covering prehistoric paintings in Borneo. Quaternary Research, 60(2), 172-179.

Reepmeyer, C., O'Connor, S., \& Brockwell, S. (2011). Longterm obsidian use at the Jerimalai rock shelter in East Timor. Archaeology in Oceania, 46(2), 85-90.

Reepmeyer, C., O'Connor, S., Maloney, T., \& Kealy, S. (2016). Late Pleistocene/early Holocene maritime interaction in Southeastern Indonesia-Timor Leste. Journal of Archaeological Science, 76, 21-30.

Reepmeyer, C., Spriggs, M., Lape, P., Neri, L., Ronquillo, W. P., Simanjuntak, T., ... \& Tiauzon, A. (2011). Obsidian sources and distribution systems in Island Southeast Asia: new results and implications from geochemical research using LA-ICPMS. Journal of Archaeological Science, 38(11), 2995-3005.

Ririmasse, M. N. (2007). Tinjuan Kembali Seni Cadas di Maluku. Kapata Arkeologi, 3(4), 1-21.

Röder, J. (1938). Felsbilder auf Ceram. Paideuma, 1(1), 19-28.

Röder, J. (1959). Felsbilder und Vorgeschichte des MacCluerGolfes, West Neuguinea. In Ergebnisse der Frobenius Expedition 1937-38 in die Molukken und nach Holländisch NeuGuinea. Bd. IV. Darmstadt: L.C. Wittich Verlag. 
Schapper, A. (2015). Wallacea, a linguistic area. Archipel. Études interdisciplinaires sur le monde insulindien, (90), 99-151.

Spriggs, M., Reepmeyer, C., Anggraeni, Lape, P., Neri, L., Ronquillo, W. P., ... Tiauzon, A. (2011). Obsidian sources and distribution systems in Island Southeast Asia: A review of previous research. Journal of Archaeological Science, 38(11), 2873-2881. 